\title{
KARL ROKITANSKY: HIS BOHEMIAN YEARS AND HIS RELATIONSHIP WITH JAN EVANGELISTA PURKYNĚ
}

\section{On the occasion of bicentenary of birth}

\begin{abstract}
Ivo Šteiner
Charles University in Prague, Faculty of Medicine in Hradec Králové, Czech Republic: The Fingerland Department of Pathology

Summary: Karl Rokitansky was born on $19^{\text {th }}$ February 1804 in the historic Czech town of Hradec Králové (Königgrätz). During 1821-1824 he studied for 3 years at the medical faculty of Prague University. In the archives of Charles University there is a record of Rokitansky's performance during these three years. At the university he met J. E. Purkyně who was teaching anatomy at that time. Relationship between the two world - renowned medical scientists of Czech origin is discussed.
\end{abstract}

Key words: Rokitansky; Purkyně; Charles University

Karl Rokitansky was born on $19^{\text {th }}$ February 1804 in the historic Czech town of Hradec Králové (Kőniggrätz), the capital of Eastern Bohemia. During the second half of the $18^{\text {th }}$ century, the empress Maria Theresia had transformed the town into a military fortress surrounded by a belt of fortifications and the size of its civilian population had reduced to a mere 3500 (5). Rokitansky was probably born in house number 42 near the Large Square, close to the Cathedral of the Holy Spirit, the house now identified by a memorial plaque stating, in Czech: "Karel Rokitansky was born here on $19^{\text {th }}$ February 1804". The relief on this

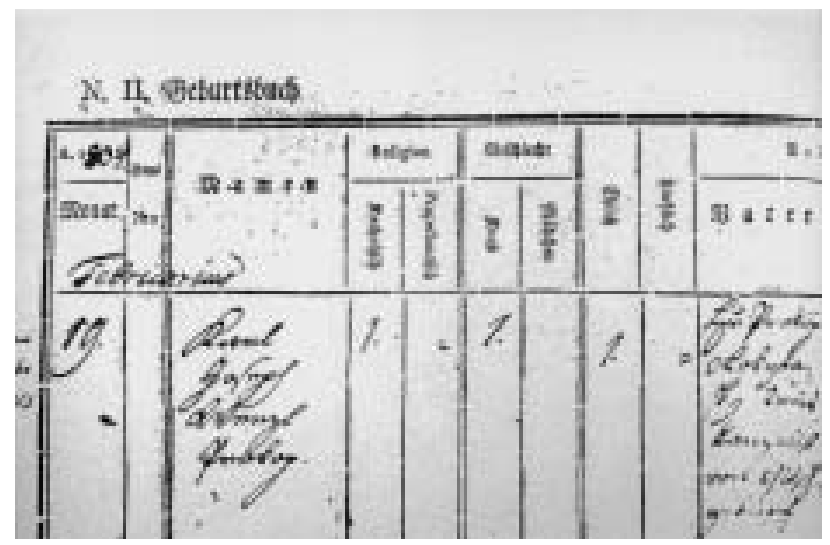

tablet is the work of the renowned Czech sculptor Myslbek, who was also responsible for the statue of Saint Wenceslas in Wenceslas Square, Prague. The plaque was unveiled with due ceremony in 1879, a year after Rokitansky's death (9).

Karl was the first child of his parents, born, interestingly enough, just five months after their wedding. In the "Geburtsbuch" the full name of the newborn Rokitansky is recorded as "Karl, Joseph, Wenzl, Prokop". His father Prokop's profession is given as "Kreiskanzelist"; his mother's name as Theresia (figs. 1, 2). During subsequent years, three more children were born into the family: Prokop, Marie and

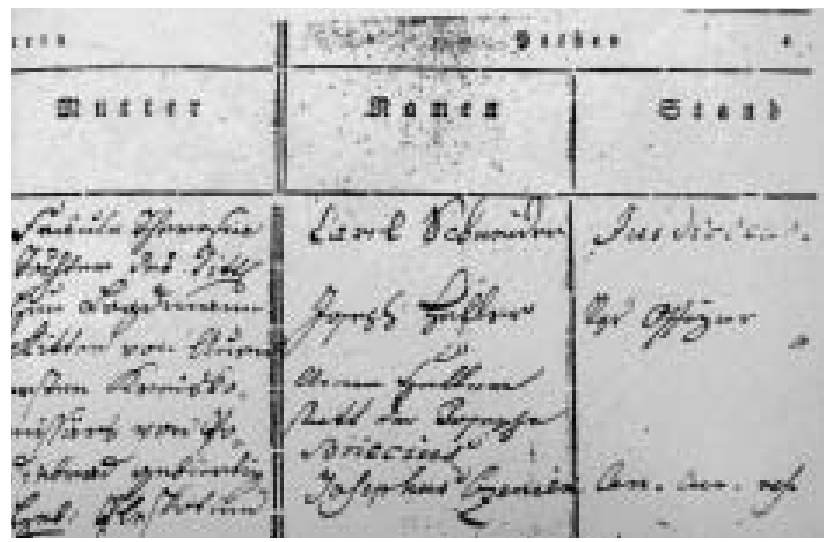

Figs. 1,2: Inscription in the Book of Births (Geburtsbuch) of Hradec Králové on the birth of Karl Rokitansky. (1): Namen - Karl, Joseph, Wenzl, Prokop. Vater - Prokop Rokytansky, Kreiskanzelist von Jitschin gebürtig.

(2): Mutter - Theresia Tochter des Tittl. Herrn Logdmann Ritter von Auen ersten Kreiskomissärs von Podiebrad gebürtig. 
Theresie. When Karl was eight, his father died at the age of just 42 years and his widow, with four children, struggled to make ends meet. Between 1813 and 1818, Rokitansky attended the Hradec Králové grammar school ("gymnasium”), moving to Prague in 1818 to study, for three years, so-called "philosophy", which was mandatory before university (10). In 1821, he enrolled at the medical faculty of Prague University, which was at that time known as "Charles-Ferdinand University".

The medical faculty was located in the contemporary historic building of Charles University, the Carolinum. On the ground floor, a cloakroom today was, in Rokitansky's time here, the anatomical autopsy room. One can still see

\section{פDebightilide \$orlefunget. \\ Eี⿰ exten gabre. \\ iteft bitite.}

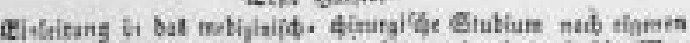

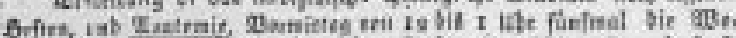

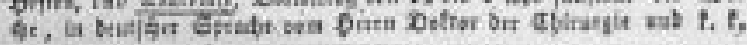

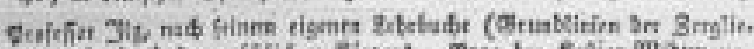

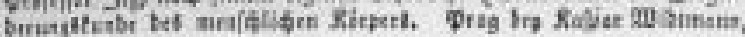
rist).

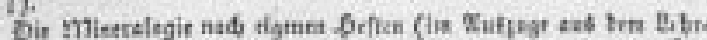

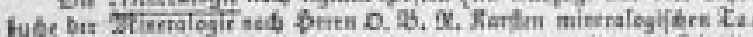

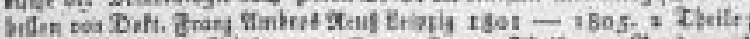

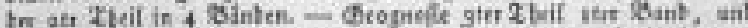

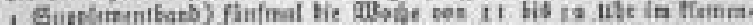

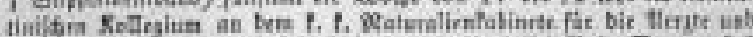

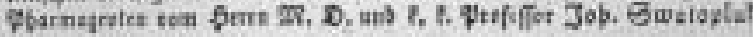
prefil.

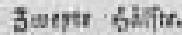

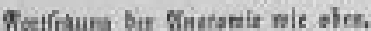

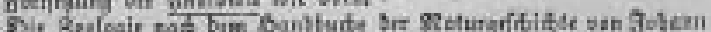

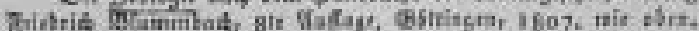

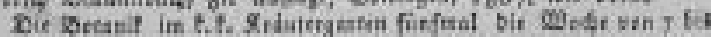

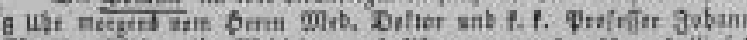

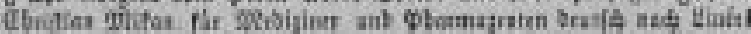

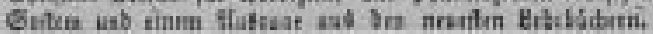

Fig. 3: Medical curriculum (Medizinische Vorlesungen) of Prague University for the first year in 1821/22.

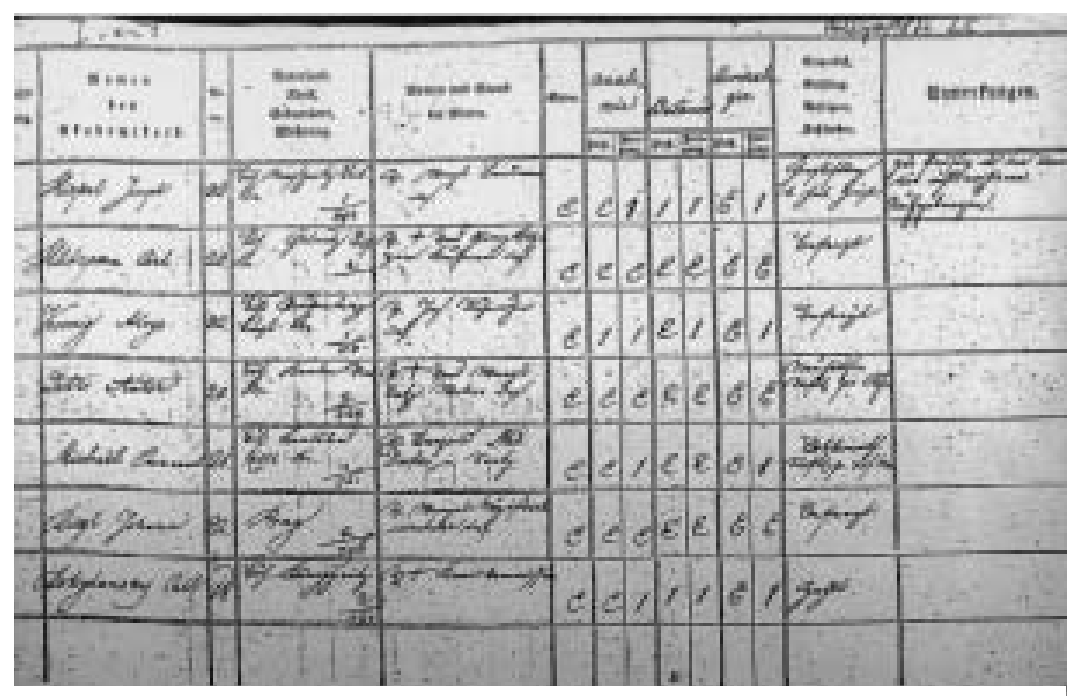

Fig. 4: A list from the catalogue of students $1821 / 22$, summer semester. Rokitansky's record is on the last line. here where ribs were broken off the gothic ceiling, a measure taken at that time to prevent flakes of facade falling down on to prosectors and cadavers. The lecture hall of the medical faculty used to be on the first floor. Nowadays, this is the small aula, the venue for meetings of the University's Scientific Board. The medical past of this hall is evidenced in a painting of the saints Cosmas and Damian, patrons of the profession of medicine.

Rokitansky spent in Prague the first three years of his medical studies. According to the archives of the University, students of medicine during these three years numbered 20 in his first year 1821/22, 22 in his second year $1822 / 23$, and just 15 in his third year $1823 / 24$. Of these 15 , only eight had been colleagues of Rokitansky for the full duration since he began his studies there three years before.

The course at that time lasted five years. The first two years were devoted to theoretical subjects, the remaining three years to clinical subjects. Studies each year started on the first of November and finished the last day of August. The vacations were in September and October. The school year was divided into a winter and summer semester. Some lectures were given in Latin, others in German, and they were given, for the most part, according to certain prescribed textbooks. Lectures were held daily, including Saturday, and there were few holidays, only at the New Year and Easter (2).

From the University's „Verzeichniss der Ordentlichen und Aussordentlichen Vorlesungen“ (fig. 3) we are informed about the subjects that comprised the medical curriculum.

In the first half of the first school year only Anatomy and Natural Sciences (Zoology and Mineralogy) were given; in the second semester, lectures on Botany were added. All subjects were five hours a week, daily from Monday to Friday. Examinations were held in winter on Anatomy and Zoology, and in summer on Anatomy, Mineralogy and Botany.

In the second year only lectures on Advanced Anatomy (Hohere Anatomie) and Physiology were given together with Chemistry and Pharmacy. In both semesters examinations on Advanced Anatomy and Chemistry were held.

In the third year studies began on medicine proper, by lectures on General Pathology (Allgemeine Pathologie und Therapie), Pharmacology, Theoretical Surgery (Grundische Chirurgie), and the Theory of Obstetrics. In the summer semester there was added Ophthalmology and the science of the use of surgical instruments and bandaging. The third year was most extensive in the number of lectures as well as in the number of examinations.

In the archives of Charles University there is a record of Rokitansky's performance during these three years, from which it becomes apparent that, accord- 
ing to the marks he achieved, he was by no means an outstanding student! Most of his final marks are "1", which corresponds to "good". Omitting marks for "manners" ("Sitten"), he achieved marks of "E", for "Eminenter", meaning "excellent", on only two occasions - during his first year, for Anatomy, and his third year, for Theoretical Surgery (Figs. 4,5).

Also within these annals, there is an interesting finding regarding the spelling of our subject's name. This is recorded four times and each time the spelling is different: $i$ versus $y$, and $y$ versus $y$ in Rokitansky, and $c$ versus $k$ in Karl (fig. 6). If, in addition, we consider one further official version in the "Geburtsbuch", we arrive, curiously, at a total of five alternative spellings of his name!

It is apparent from Rokitansky's own biography (8) that his personal situation in Prague was not of the best. In order

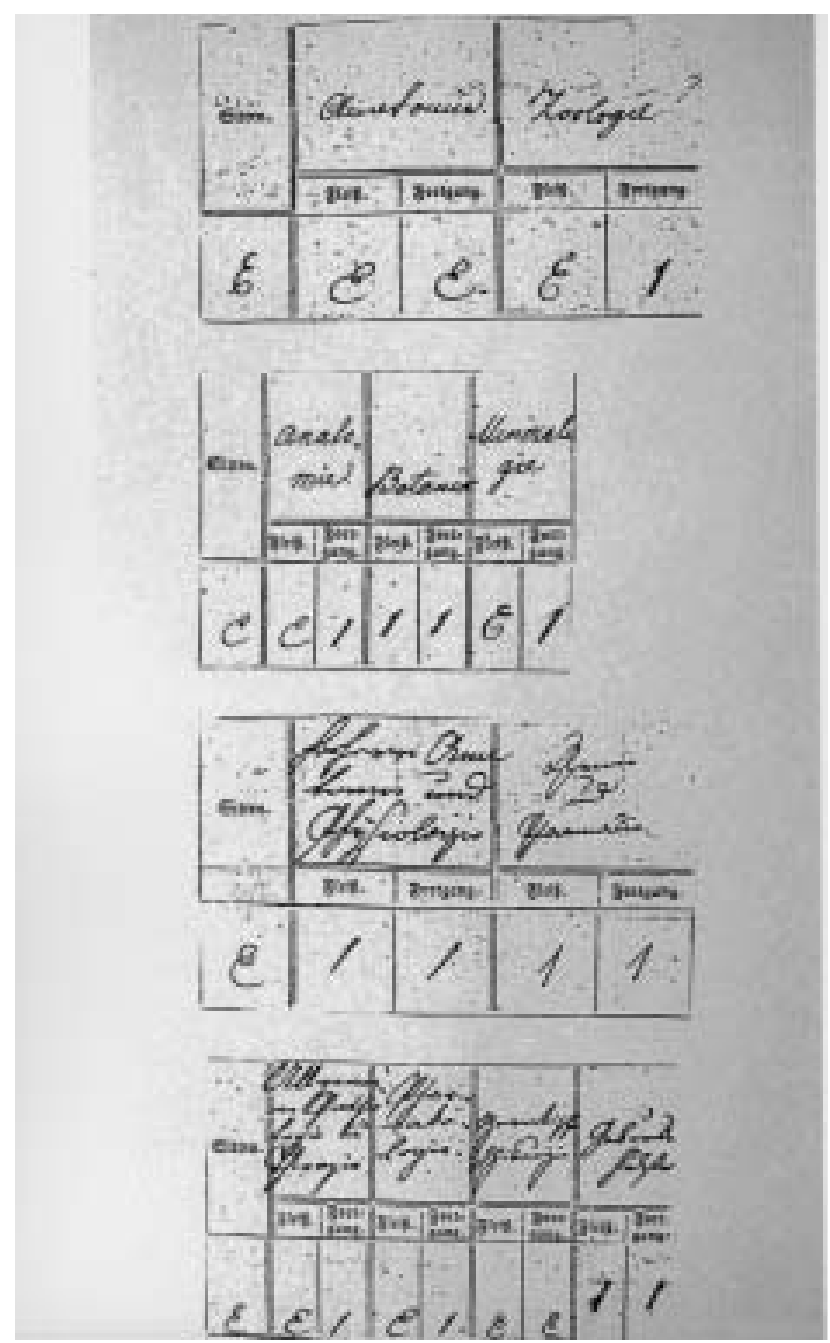

Fig. 5: Rokitansky's marks during his studies in Prague, extracted from the catalogues of students; from top to bottom: first year - winter semester 1821/22; summer semester $1821 / 22$; second year 1822/23; third year 1823/24. For details see text. to earn money, for example, he was forced to give private lessons, and there is further evidence for his financial problems in the official records of Charles University. Here, it is recorded that, although he managed to pay his tuition fees for the first and second years of his studies there, he was exempted from such payment for $1823 / 24$, his third and final year.

In the autumn of 1824, at the age of 20, Rokitansky left Prague for Vienna. But that is another story...

In the second part of this paper, I would like to say something about the relationship between Rokitansky and another world-renowned medical scientist of Czech origin, J. E. Purkyně. Incidentally, both may be seen on the famous frescoes of Diego Rivera at the Cardiological Institute in Mexico City (figs. 7, 8). These depict those who have contributed most to the science of cardiology, Rokitansky being

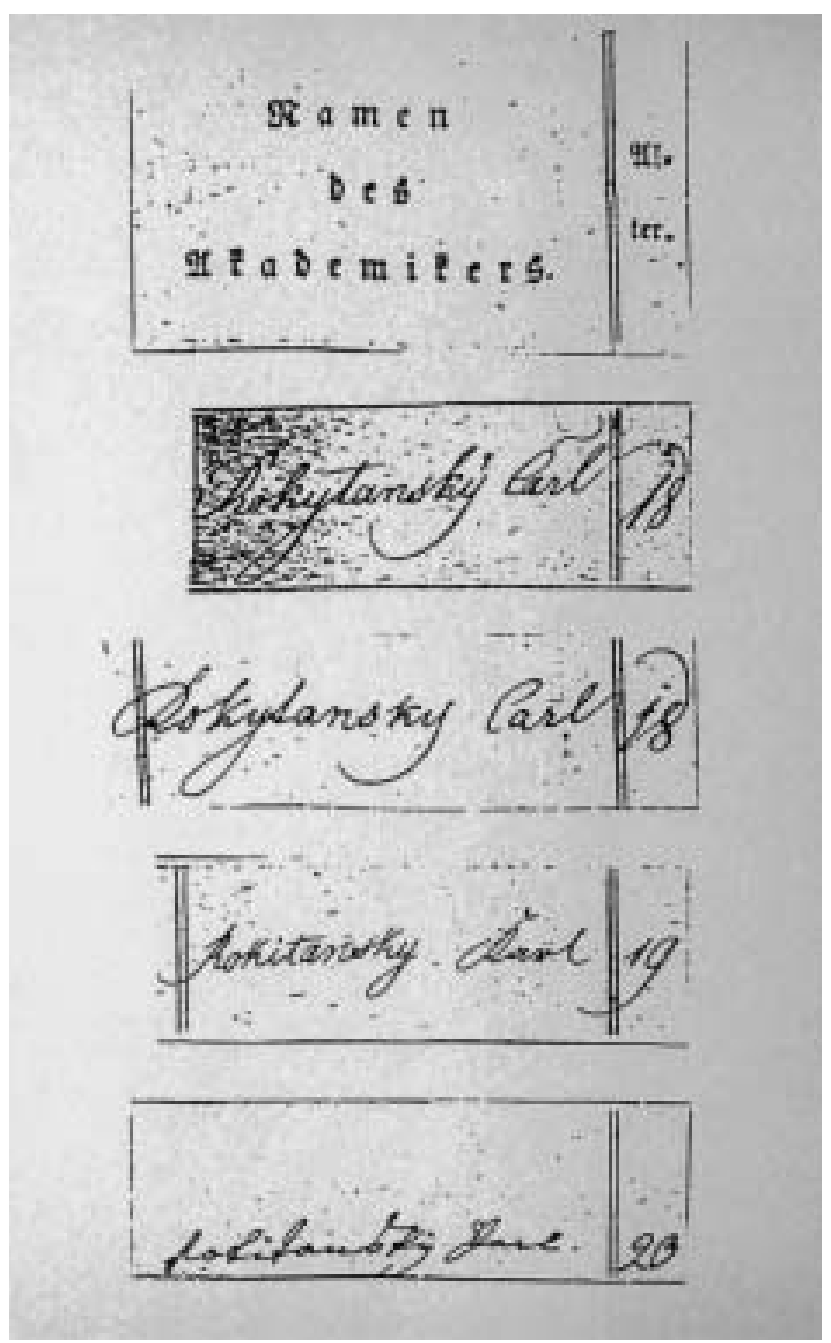

Fig. 6: Four different spellings of Rokitansky's name extracted from inscriptions in the catalogues of students. The same order like in fig. 5. 

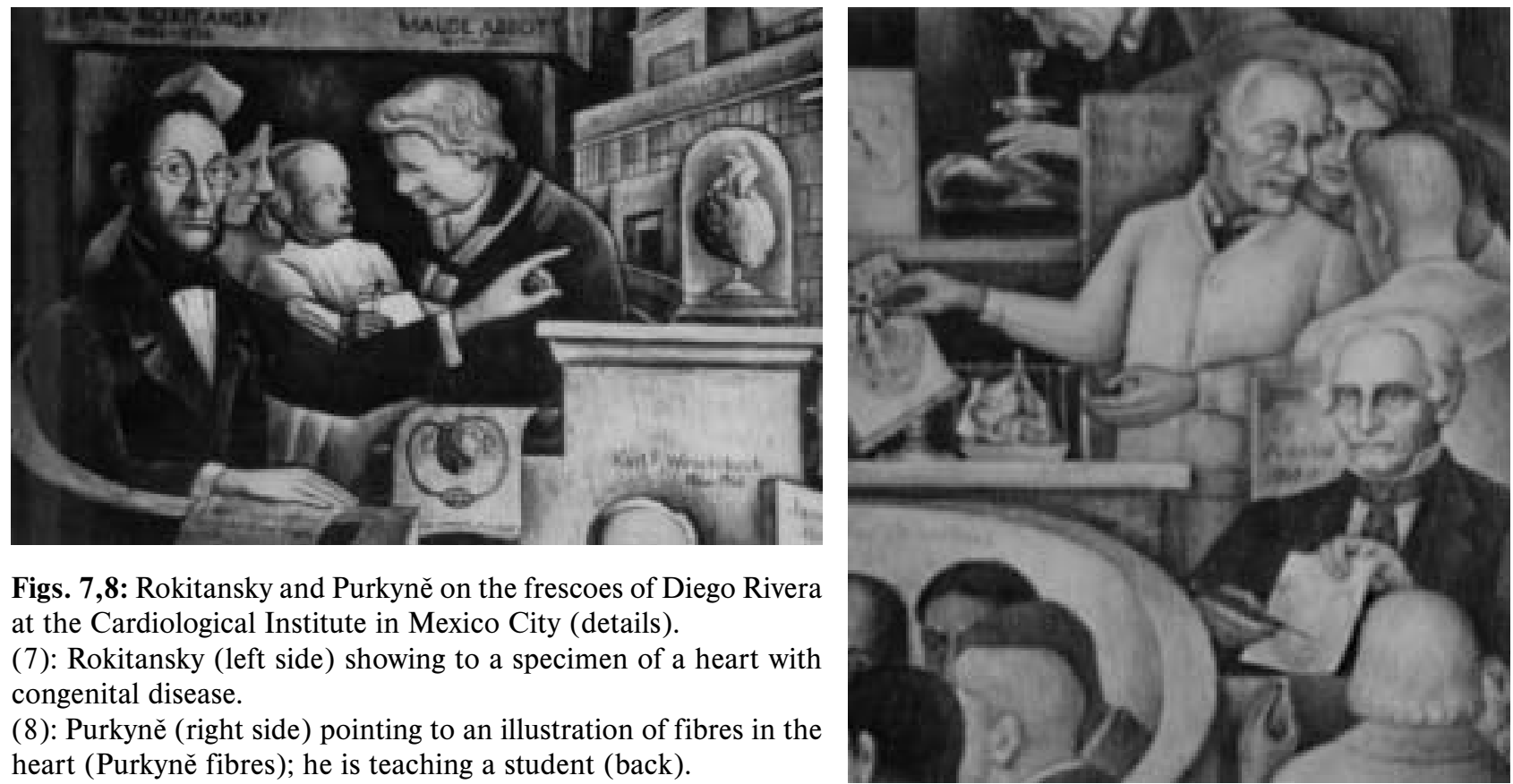

Figs. 7,8: Rokitansky and Purkyně on the frescoes of Diego Rivera at the Cardiological Institute in Mexico City (details).

(7): Rokitansky (left side) showing to a specimen of a heart with congenital disease.

(8): Purkyně (right side) pointing to an illustration of fibres in the heart (Purkyně fibres); he is teaching a student (back).

present by virtue of his first systematic studies of congenital heart disease (7) and the thrombogenic theory of atherosclerosis, and Purkyně because of his discovery of the terminal components of the cardiac conduction system that now bear his name and are known universally as "the fibres of Purkyně" (11).

There were, however, some fundamental differences between these two eminent men. For example, whereas Rokitansky was a loyal citizen and supporter of the monarchy, Purkyně was a Czech patriot in favour of federalization and to the Austrian government (I am quoting here) "an incorrigible old man" and "the leader of the Czech separatists" (2).

Purkyně was born in 1787 , sixteen years before Rokitansky. In 1818, he graduated from the Prague medical faculty and, in 1819, was appointed in the Department of Anatomy there as assistant to Professor Johann Georg Ilg. As I have already mentioned, Rokitansky embarked upon his medical studies in Prague in the autumn of 1821 such that Purkyně was his anatomy teacher during his first year there. Later, in his autobiography (8), Rokitansky comments on this encounter: "Im Seciersaale gab es keine Anleitung, da Prosektor Purkyně - der nachmalige Physiologe - sich kaum sehen liess, und auch, wenn er kam, uns nicht beachtete". This criticism is in some ways difficult to understand, since it is clear from his later time in Breslau, and subsequently again in Prague, that Purkyně's lectures were highly valued and that, as a teacher, he was held in great affection by his students. We also know, however, that the years from 1820 to 1822 were difficult for Purkyně; he applied repeatedly but in vain for a professorship, in Prague, Pest, and also in Graz, and was also involved in a difficult relationship with a young woman, Adleta Desfour. The effects of this stressful situation may to some extent explain Rokitansky's poor opinion of him! (4).

Purkyně left Prague University for the then Prussian city of Breslau (now Polish Wroclaw) in April 1823, where he was eventually appointed to the chair of Physiology and was followed 18 months later by Rokitansky himself, who moved from Prague to Vienna. As far as I know, there was no further contact between the two men for 40 years. In the meantime, Purkyně returned to Prague in 1850, having spent 27 years in Breslau, the most fruitful ones of his life. During this second period in Prague, he was not only a professor of the university and eminent scientist, but also an ardent patriot and one of the leading personalities of the Czech revival.

In 1863, in Vienna, Hofrath Rokitansky was appointed as a medical expert in the Ministry of Culture and Education (fig. 9), from which position he issued two booklets recounting his views concerning the role of universities and of medical faculties in particular: "Zeitfragen betreffend die Universität mit besonderer Beziehung auf die Medizin” and "Die Conformität der Universitäten mit Rücksicht auf gegenwärtige oesterreichische Zustände”. In these, he suggests that the Austrian universities be organized on a uniform basis with the University of Vienna pre-eminent. It was Purkyně who dared to challenge him. In the recently founded Czech Medical Journal he published, in 1863 and 1864, two papers sharply criticizing Rokitansky's proposals, arguing that universities should not be regarded merely as institutions for learned men, but also as places where students could be practically educated and where the national and linguistic problems of Austria could be dealt with 


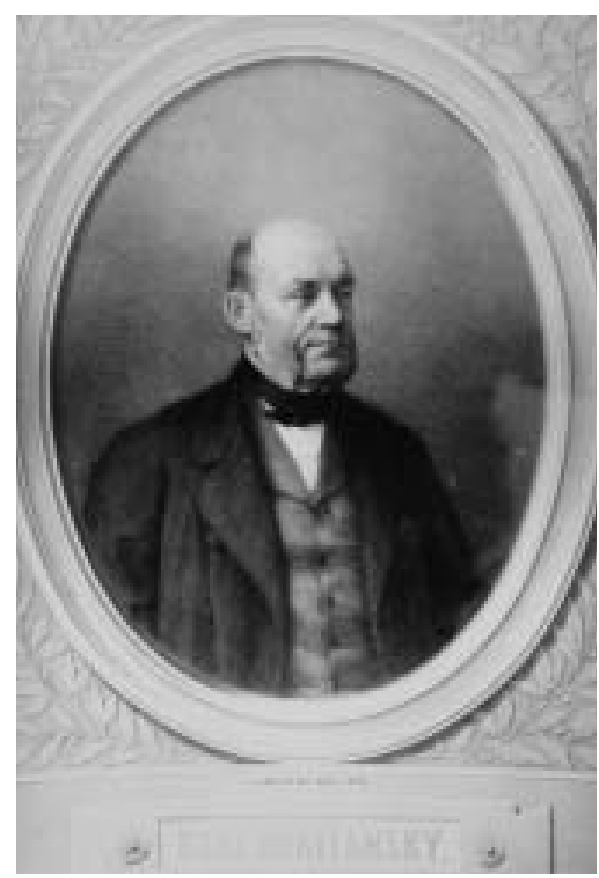

Fig. 9: Karl Rokitansky - engraving by L. Jacoby, 1872.

also. Nor did Purkyně agree with Rokitansky's views concerning the pre-eminence of the University of Vienna, suggesting instead that provincial universities with equality of language should be established in individual countries of the monarchy $(1,2,6)$.

By 1865, Purkyně was approaching his eightieth year and his activity was declining considerably (fig. 10). It was suggested, largely by the German contingent of the university, that he might be pensioned off. However, Rokitansky, who was in the position of having the power to agree such a decision, had great respect for Purkyně despite their previous differences. Correspondence between the two shows how Rokitansky tactfully suggested that, should Purkyně agree to retire, the latter's terms regarding his pension, the building of a new Department of Physiology and also the identity of his successor would be met. On this basis, Purkyně agreed to retire. Influenced by his students, however, he changed his mind and continued in his chair, Rokitansky eventually declining from his position of power $(2,3)$. Eventually, on Rokitansky's recommendation, Purkyně was knighted and, a year before his death in 1869, was awarded the Austrian Order of Leopold.

And Rokitansky died nine years later...

\section{Acknowledgments}

I am grateful to Prof. J. Petráň, Prof. L. Chrobák and Mgr. J. Štěpán for their contribution to this study, to Dr. J. Gosney for reviewing the manuscript, and to Mrs. A. Hejnová and Mrs. B. Šepsová for technical assistance.

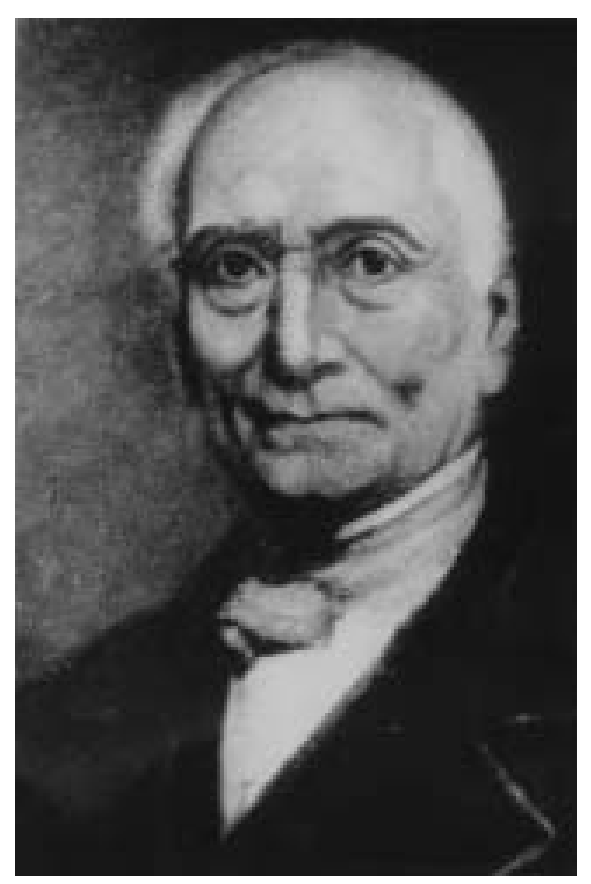

Fig. 10: Jan Evangelista Purkyně - oil painting by the scientist's son Karel Purkyně, 1864.

\section{References}

1. Bouček B. Purkyně and Rokitansky on Austrian universities. Čas Lék čes 1950;89:1095-7 (In Czech).

2. John HJ. Jan Evangelista Purkyně, Czech scientist and patriot, 1787-1869. Philadelphia: The American Philosophical Society, 1959:1-53.

3. Kruta V. Documents concerning the last years of J. E. Purkyne at the Prague University. Acta Univ Carolinae 1970;11:52-73 (In Czech).

4. Kruta V. Students and collaborators of J. E. Purkyně. II Teaching onsets in Prague 1818-1823. C. Boháčz and K. Rokitansky. Čas Lék čes 1970;109: 1098-100 (In Czech).

5. Mikulka J. History of Hradec Králové II/2. Hradec Králové: Historica, 1995 177-350 (In Czech).

6. Purkyně JE. Opera omnia VII. Praha: Czechoslovak Academy of Sciences, 1958:289-95;430-2 (In Czech)

7. von Rokitansky C. Die Defecte der Scheidewände des Herzens. Wien: W. Braumüller, 1875

8. von Rokitansky C. Selbstbiographie und Antrittsrede. Eingeleitet, herausgegeben und mit Erläuterungen versehen von Erna Lesky. Wien: Hermann Böhlaus Nachf, 1960:47-8.

9. Stefan H. Rokitansky memorial plaque. Čas Lék čes 1954;93:939-41 (In Czech).

10. Stefan H. Karel Rokitansky. Hradec Králové: Dům osvěty, 1954:1-76 (In Czech).

11. Steiner I. History of the Purkyně fibres in the heart. Sbor věd prací Hradec Králové 1987;30:7-20.

Submitted February 2004

Accepted March 2004

Prof. MUDr. Ivo Šteiner, CSc., University Hospital,

The Fingerland Department of Pathology, 50005 Hradec Králové, Czech Republic. e-mail: steiner@lfhk.cuni.cz 